\title{
PEMODELAN SUMBER GEMPA DI WILAYAH SULAWESI UTARA SEBAGAI UPAYA MITIGASI BENCANA GEMPA BUMI ${ }^{1)}$
}

\author{
Guntur Pasau $^{2)}$ dan Adey Tanauma ${ }^{2)}$ \\ e-mail: pasaujunior@gmail.com \\ ${ }^{1)}$ Penelitian IPTEK dan Seni dengan Biaya DIPA Unsrat Tahun 2011 \\ ${ }^{2)}$ Progran Studi Fisika FMIPA Universitas San Ratulangi Manado, 95115
}

\begin{abstract}
ABSTRAK
Pemodelan sumber gempa di wilayah Sulawesi Utara telah dilakukan. Pemodelan sumber gempa menggunakan teori probabilitas total merupakan salah satu upaya mitigasi dalam mengetahui besarnya percepatan suatu gerakan tanah yang diakibatkan oleh suatu gempa bumi. Analisis perhitungan percepatan tanah maksimum di batuan dasar meliputi probabilitas terlampaui $10 \%$ dalam 50 tahun. Hasil analisis pemodelan sumber gempa yang telah dilakukan didapatkan bahwa nilai percepatan tanah pada beberapa kota besar di Sulawesi Utara cukup tinggi. Nilai percepatan tanah maksimum yang tertinggi adalah Kota Gorontalo dengan nilai percepatan sekitar $0,5 \mathrm{~g}$ kemudian disusul oleh Kota Bitung sebesar 0,4g, dan Kota Manado sebesar 0,25g.
\end{abstract}

Kata Kunci: pemodelan, sumber gempa, probabilitas, percepatan, batuan dasar.

\section{EARTHQUAKE SOURCE MODELING OF NORTH SULAWESI REGION AS AN EFFORT OF EARTHQUAKE DISASTER MITIGATION}

\begin{abstract}
Earthquake source modeling of North Sulawesi region was carried out. The earthquake source modeling using the theory of total probability is one of the mitigation efforts in knowing the magnitude of the acceleration of the ground motion caused by an earthquake. Analysis of the calculation of the maximum ground acceleration at bedrock includes the probability of exceedance $10 \%$ in 50 years. The results of the earthquake source modeling analysis has been done found that the ground acceleration values in some major cities in North Sulawesi is quite high. The maximum ground acceleration value of the highest is the of Gorontalo City with a value of about $0.5 \mathrm{~g}$ acceleration was followed by the Bitung City of $0.4 \mathrm{~g}$, and the Manado City of 0.25 g.
\end{abstract}

Keywords: modeling, earthquake source, probability, accelearation, bedrock

\section{PENDAHULUAN}

Indonesia terletak pada batas pertemuan tiga lempeng besar dunia yang sangat aktif yaitu lempeng Eurasia, lempeng Pasifik, dan lempeng Indo-Australia serta satu lempeng mikro yaitu lempeng mikro Filipina, karena itu maka wilayah Indonesia sangat rawan terhadap bencana gempagempa tektonik (Gambar 1).

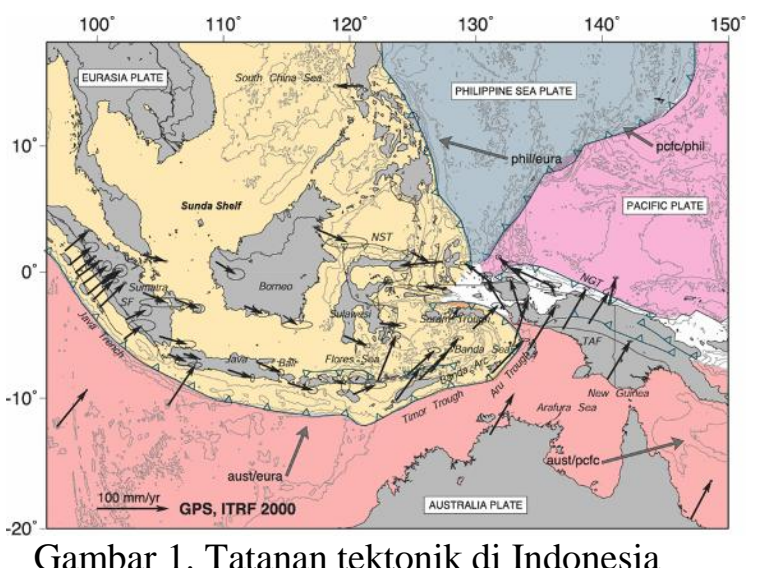

Gambar 1. Tatanan tektonik di Indonesia (Bock dkk, 2002). 
Akibat tumbukan antara lempeng itu maka terbentuk daerah penunjaman atau subduksi. Daerah penunjaman oleh lempeng Indo-Australia memanjang di sebelah Barat Pulau Sumatera, sebelah Selatan Pulau Jawa hingga ke Bali dan Kepulauan Nusa Tenggara bergerak ke utara sekitar 50-70 $\mathrm{mm} / \mathrm{tahun}$. Kemudian di sepanjang tepian Lempeng Kepulauan dari Pulau Timor ke arah Timur dan terus memutar ke Utara berlawanan arah jarum jam menuju wilayah perairan Maluku, Lempeng Benua Australia menabrak dengan kecepatan sekitar 70 $\mathrm{mm} /$ tahun. Jadi di wilayah ini yang terjadi bukan penunjaman lempeng lautan lagi tapi zona tumbukan lempeng benua terhadap lempeng kepulauan. Di utara Indonesia Timur, Lempeng Pacifik menabrak sisi utara Pulau Irian dan pulau-pulau di utara Maluku dengan kecepatan $120 \mathrm{~mm} / \mathrm{tahun}$, dua kali lebih cepat dari kecepatan penunjaman lempeng di bagian sisi Barat dan Selatan Indonesia. Sementara yang lebih kompleks dan rumit adalah penunjaman pada pertemuan antara beberapa lempeng yang terjadi dibagian utara pulau Sulawesi dan kawasan Laut Maluku. Di kawasan ini terdapat subduksi ganda, akibat subduksi (penunjaman) lempeng Pasifik terhadap lempeng Eurasia menimbulkan dua busur melengkung yang arahnya berbeda, yaitu busur Halmahera dan Busur Mayu-Sangihe. Busur Mayu sejajar dengan Halmahera, menunjam ke arah timur. Sedang Busur Halmahera menunjam ke barat mengarah ke Filipina dan Perairan Maluku.

Tekanan dahsyat karena pergerakan dari empat lempeng besar bumi ini menyebabkan interior lempeng bumi dari Kepulauan Indonesia terpecah-pecah menjadi bagian-bagian kecil kerak bumi yang bergerak antara satu terhadap lainnya yang dibatasi oleh patahan-patahan aktif. Karena itu, kepulauan Indonesia berada pada daerah yang mempunyai aktivitas gempa bumi cukup tinggi yang mengakibatkan bencana alam akibat gempa bumi di Indonesia makin sering terjadi. Berkaitan dengan kondisi tersebut, salah satu upaya yang bisa dilakukan untuk meminimalkan dampak bencana gempa adalah menyiapkan semua prasarana yang dibangun di Indonesia yang tahan terhadap gempa. Pemodelan sumber gempa merupakan salah satu upaya mitigasi dalam mengetahui besarnya percepatan suatu gerakan tanah yang diakibatkan oleh suatu gempa bumi.

\section{TINJAUAN PUSTAKA}

\section{Tektonik Sulawesi Utara dan Sekitarnya}

Pulau Sulawesi dan sekitarnya, khususnya Sulawesi bagian utara merupakan salah satu margin aktif yang paling rumit dalam jangka waktu geologi, struktur dan juga tektonik. Wilayah ini merupakan pusat pertemuan tiga lempeng konvergen, karena interaksi tiga kerak bumi utama (lempeng) di masa Neogen (Simandjuntak, 1992). Konvergensi ini menimbulkan pengembangan semua jenis struktur di semua skala, termasuk subduksi dan zona tumbukan, sesar dan thrust. Saat ini sebagian besar struktur Neogen dan beberapa struktur pra-Neogen masih tetap aktif atau aktif kembali. Struktur utama termasuk Subduksi Sulawesi Utara(North Sulawesi Trench / Minahasa Trench), Sesar Gorontalo, Sulu Thrust, dan tumbukan ganda laut Maluku (Molluca sea collition) seperti ditampilkan dalam Gambar 2.

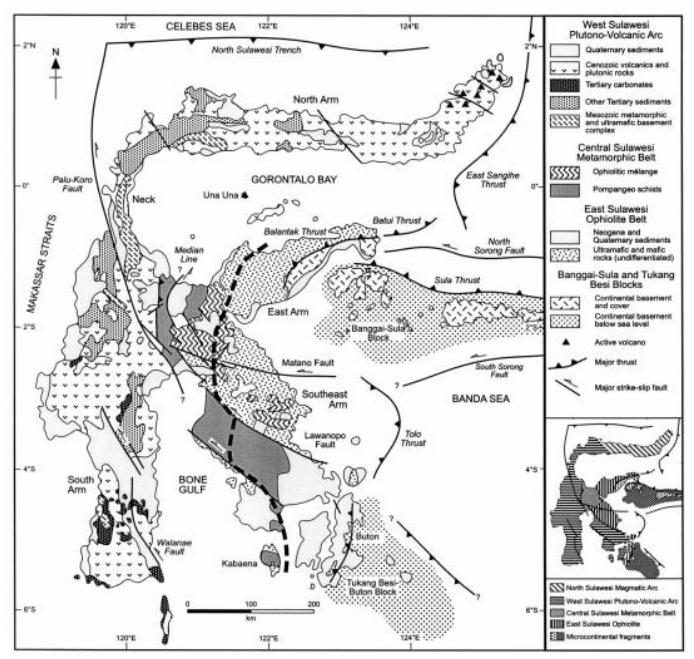

Gambar 2. Peta tektonik utama Pulau

Sulawesi (Hall dan Wilson, 2000).

\section{Zona Subduksi Sulawesi Utara}

Subduksi Sulawesi Utara (North Sulawesi Trench) diinterpretasikan merupakan zona subduksi konvergen antara Laut Sulawesi dan Lengan Utara Sulawesi. Zona subduksi Sulawesi Utara termasuk kedalam sistim penunjaman yang relatif tua (dying subduction) yang robekannya 
berkembang ke arah timur sepanjang tepian utara Sulawesi. Penunjaman Sulawesi Utara menyusup dengan sudut kemiringan sekitar $14^{0}$ dan zone benioff menunjam sampai kedalaman 170-180 km, dengan sudut kemiringan sekitar $45^{\circ}$. Magnitudo maksimum (Mmax) gempa bumi di zona Subduksi Sulawesi Utara mencapai 8,0 dengan periode ulang gempa bumi sekitar 234 tahun (Kertapati, 2006).

\section{Sesar Gorontalo}

Pada bagian utara Pulau Sulawesi, secara morfologi akan terlihat kenampakan empat segmen sesar (Hall dkk, 2000). Bagian tengah dari utara Pulau Sulawesi terbagi kedalam tiga block yang kecil. Pada bagian timur dari lengan utara Pulau Sulawesi diberi nama Block Manado, yang bebas dari pengaruh North Sula Block. Sehingga secara geologi jelas terlihat pemisahan yang diakibatkan adanya Sesar Gorontalo. Sesar Gorontalo yang memanjang dari arah barat laut ke tenggara yaitu mulai Laut Sulawesi melewati Gorontalo hingga perairan Teluk Tomoni, dan mekanisme sesarnya adalah sesar menganan (right lateral slip).

\section{Zona Tumbukan Laut Maluku}

Di bawah zona tumbukan Laut Maluku yang memanjang dalam arah utaraselatan telah diamati adanya suatu penunjaman slab dari lempeng laut Maluku dengan konfigurasi penunjaman yang sangat unik, dimana slab dari lempeng yang sama menunjam ke dua arah yaitu barat dan timur berbentuk seperti $U$ terbalik. Berdasarkan tomogram kartun 3D, nampak bahwa konfigurasi slab lempeng laut Maluku yang menunjam ke barat mempunyai kemiringan yang lebih tajam daripada yang tersubduksi ke timur. Hal ini barangkali disebabkan oleh bergesernya seluruh sistim tumbukan di Maluku ke barat oleh akibat desakan dari lempeng Pasifik yang bergerak ke barat (Widiyantoro, 2007).

\section{Pemodelan Sumber Gempa}

Pemodelan sumber gempa bumi atau pembuatan model-model seismotektonik harus dilakukan dengan berdasarkan indikasi data geologi, geodesi, geofisika dan seismologi yang mengandung informasi struktur seismogenik menerus ataupun yang terpisah (discrete). Bertitik tolak dari datadata tersebut yang ada, Kertapati (2006) dan Irsyam, dkk (2008) mengenali dan membedakan ada tiga lajur sumber gempa bumi di Wilayah Indonesia, yaitu:

a. Zona Penunjaman / Subduksi, yaitu jalur tempat terjadinya gempa bumi disekitar pertemuan antara dua lempeng dimana lempeng samudera menunjam ke dalam lempeng benua atau dua lempeng benua saling menumpu.

b. Zona patahan patahan kerak bumi dangkal "shallow crustal fault zone" tempat terjadinya gempa bumi di dalam kerak bumi dangkal.

c. Zona menyebar (diffuse) yaitu jalur sumber gempa yang diasumsikan sebagai daerah yang mempunyai potensi kegempaan yang sama.

\section{Analisis Seismik}

Metode yang sering digunakan dalam analisis seismik hazard adalah metode probabilistik. Metode Probabilitas Total yang dikembangkan McGuire (1976) berdasarkan konsep probabilitas dari Cornell (1968). Teori ini menggunakan asumsi bahwa suatu kejadian gempa dengan magnitude, $\mathrm{M}$ dan jarak hiposenter, $\mathrm{R}$ sebagai variabel acak indenpenden yang kontinu. Teori probabilitas total dapat dinyatakan dalam formula dasar sebagai berikut,

$P[I \geq i]=\iint_{r m} P[I \geq$

$i \mid m$ and $r] . f M(m) . f R(r) d m d r$ dimana,

$f M$ : fungsi distribusi magnitude

$f R$ : fungsi distribusi jarak hiposenter

$P[I>i \mid m$ dan $r]$ : probabilitas bersyarat dari intensitas $I$ yang melampaui nilai i pada lokasi yang ditinjau untuk kejadian gempa dengan magnitude $\mathrm{m}$ dan jarak hiposenter $r$ 


\section{Parameter Gempa}

Frekuensi atau jumlah gempa bumi adalah merupakan karakteristik basis dari aktifitas seismik di suatu daerah selama selang waktu tertentu. Parameter ini merupakan model matematis yang menggambarkan tentang aktifitas suatu gempa yang terjadi pada batuan dasar di suatu daerah. Metode Least Square atau model Guttenberg-Ricter: frekuensi terjadinya gempa dengan magnitudo $M \geq m$ persatuan waktu, menurun secara ekponensial dengan meningkatnya magnitudo gempa. Hubungan tersebut dapat dinyatakan sebagai berikut:

$\begin{aligned} & \log N(m)=a-b M \\ & N(\mathrm{~m}): \text { frekuensi terjadinya gempa............ (2) } \\ & \text { dengan magnitude } M \geq m \text { per } \\ & \text { satuan waktu } \\ & M \quad: \text { magnitudo gempa. } \\ & \mathrm{a}: \text { konstanta karakteristik daerah } \\ & \text { gempa yang tergantung pada } \\ & \text { jangka waktu pengamatan dan } \\ & \text { tingkat kegempaan daerah } \\ & \text { sumbernya. } \\ & \mathrm{b} \quad \text { konstanta karakteristik daerah } \\ & \text { gempa yang menyatakan } \\ & \text { penyebaran relatif dari magnitude } \\ & \text { gempa pada sembarang sumber } \\ & \text { titik pada daerah gempa. }\end{aligned}$

\section{METODE PENELITIAN}

\section{Studi Literatur dan Pengumpulan Data}

Data yang digunakan dalam penelitian ini adalah data gempa yang pernah terjadi disekitar pulau Sulawesi dari bulan April tahun 1963 sampai bulan Juli 2011. Data dikumpulkan dari dua katalog yakni USGS dan ANSS. Parameterparameter geologi, geodesi dan geofisika yang digunakan bersumber dari studi literatur (jurnal dan penelitian-penelitian terdahulu lainnya). Wilayah katalog dari $120^{\circ} \mathrm{BT}-130^{\circ} \mathrm{BT}$ dan $2^{0} \mathrm{LS}-5^{\circ} \mathrm{LU}$. Skala magnitudo minimum yang digunakan adalah $M_{w} \geq 5$ dengan kedalaman maksimum sebesar $300 \mathrm{~km}$.

\section{Penyeragaman Skala Magnitudo}

Penyeragaman skala magnitudo gempa ini dilakukan dengan cara mengkonversi berbagai skala magnitudo kedalam skala magnitudo momen (moment magnitude, $M_{w}$ ). Momen magnitudo merupakan besaran magnitudo gempa yang terbaik dan konsisten dalam menunjukkan besar kekuatan gempa. Dalam penelitian ini hubungan empiris yang digunakan untuk penyeragaman magnitudo antara magnitudo gelombang permukaan $\left(M_{s}\right)$, magnitudo gelombang badan $\left(m_{b}\right)$ dan momen magnitudo $\left(M_{w}\right)$ adalah persamaan yang diusulkan oleh Scordilis (2006).

\section{Sortir Gempa Utama}

Sortir gempa merupakan proses pemisahan antara gempa utama (mainshock) dari gempa-gempa rintisan (foreshock) dan gempa-gempa susulan (aftershock) dengan menggunakan kriteria rentang waktu dan rentang jarak. Proses pemisahan gempa utama dari gempa-gempa rintisan dan susulan ini menggunakan metode kriteria empiris yang diusulkan oleh Gardner dan Knopoff (1974), yang dalam proses pemisahannya dilakukan dengan bantuan software ZMAP (Wiemar, 2001).

\section{Identifikasi dan Pemodelan Zona Sumber Gempa bumi}

Pada langkah ini identifikasi dan pemodelan terhadap sumber gempa dan mekanismenya meliputi lokasi, dimensi, jenis mekanisme sumber gempa dan tingkat aktifitasnya berdasarkan data gempa dari katalog dan penelitian sebelumnya.

Ada tiga model sumber gempa yang digunakan dalam studi ini yaitu:

a. Sumber gempa sesar

b. Sumber gempa subduksi

c. Sumber gempa background (gridded seismicity).

\section{Penentuan parameter seismik}

Penentuan parameter $a$ dan $b$ ditentukan dari Guttenberg Richter recurrence relationship dengan menggunakan analisis Least Square. Nilai $a$ dan $b$ ditentukan berdasarkan data yang dikelompokkan dari beberapa area ke dalam sekelompok data dengan analisa statistik model maximum likelihood. Estimasi parameter $a$ dan $b$ menggunakan analisa statistik model maximum likelihood karena memberikan hasil yang lebih stabil karena memodelkan kemiringan garis bukan dari hasil fitting least square tiap magnitudo, tapi 
kemiringan nilai tengah (mean) magnitudo fungsi distribusi Gaussian.

\section{Penentuan Fungsi Atenuasi}

Fungsi atenuasi memerlukan data ground motions (peak ground acceleration) yang cukup banyak supaya bisa mendapatkan hasil regresi yang baik. Meski saat ini banyak persamaan atenuasi yang dihasilkan, namun Indonesia sampai dengan saat ini belum memiliki data ground motions yang cukup untuk pembuatan fungsi atenuasi.

\section{Penggunaan Logic Tree}

Untuk mengatasi ketidakpastian pada parameter yang digunakan ketika kita melakukan perhitungan analisis seismik hazard maka dalam software USGS PSHA 2007 digunakan sistim pembobotan pada beberapa parameter. Model dari logic tree dari satu seri nodal (node) yang merepresentasikan titik dalam mana model dispesifikasikan dan cabang yang merepresentasikan model yang berbeda yang dispesifikasikan pada tiap nodal. Penjumlahan probabilitas dari semua cabang yang dihubungkan dengan satu nodal nilainya harus sama dengan 1 (satu).

\section{Analisa Seismik Hazard}

Analisis Seismik Hazard dilakukan dengan bantuan program USGS-PSHA 2007. Adapun sumber gempa yang digunakan adalah background source, fault source dan subduction source. Hasil akhir dari analisa hazard ini adalah meliputi peta percepatan gempa maksimum di batuan dasar pada periode $\mathrm{T}=0$ detik atau biasa juga disebut PGA (peak ground acceleration) untuk probabilitas terlampaui $10 \%$ dalam 50 tahun. Resiko gempa adalah kemungkinan terlampauinya (probability of exceedance) suatu gempa dengan intensitas tertentu selama masa bangunan. Nilai dari resiko gempa secara matematik dinyatakan dalam persamaan (3).

$$
R_{n}=1-\left(1-R_{a}\right)^{N}
$$

$$
\text { dimana, }
$$

$R_{\mathrm{n}}$ : resiko gempa

$R_{a}$ : resiko tahunan $1 / T$

$T$ : periode ulang gempa

$N$ : masa guna bangunan

\section{HASIL DAN PEMBAHASAN}

\section{Penyeragaman Skala Magnitudo}

Hasil dari penyeragaman data gempa selama selang pengamatan dari tahun 1963 sampai tahun 2011 dengan magnitudo $M w \geq 5$ dan mempunyai kedalaman maksimum sampai $300 \mathrm{~km}$. Penyeragaman kedua katalog diplot seperti yang ditampilkan pada Gambar 3 dibawah ini:

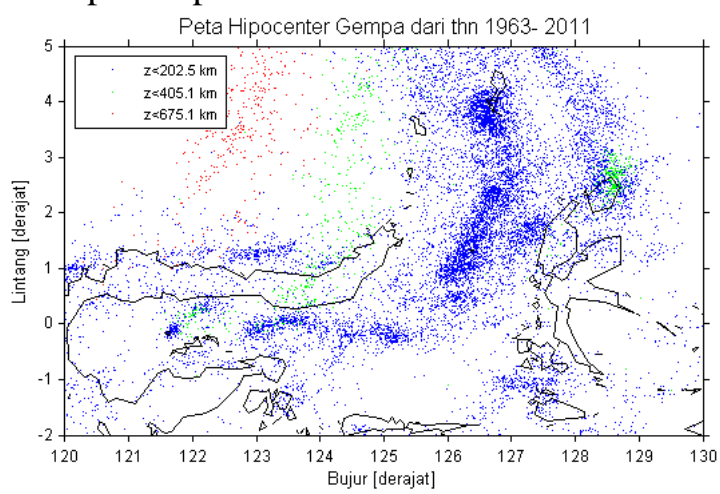

Gambar 3. Plot data gempa di daerah Sulawesi Utara dan Sekitarnya dari April 1963 hingga Juli 2011.

Dari gambar-gambar plot data tersebut didapatkan bahwa distribusi kejadian gempa utama disetiap daerah atau wilayah Sulawesi bagian utara hampir merata. Ini berbarti bahwa wilayah ini sangat rawan akan bencana gempa bumi. Gempagempa dangkal banyak terjadi di sekitar Laut Maluku akibat aktivitas tumbukan ganda laut Maluku. Sedangkan gempa-gempa menengah dan dalam kebanyakan terjadi disekitar Laut Sulawesi sebagai akibat gempa-gempa dalam dari tumbukan Laut Maluku dan penunjaman lempeng Laut Filipina. Di daratan Sulawesi Utara juga terjadi banyak gempa-gempa dangkal akibat dari aktivitas subduksi Sulawesi Utara dan juga akibat dari sesar-sesar aktiv lainnya yang ada di wilayah ini.

\section{Analisis Kejadian Gempa Utama}

Hasil pemisahan gempa utama dari gempa rintisan dan gempa susulan tersebut ditampilkan seperti pada Gambar 4 berikut: 


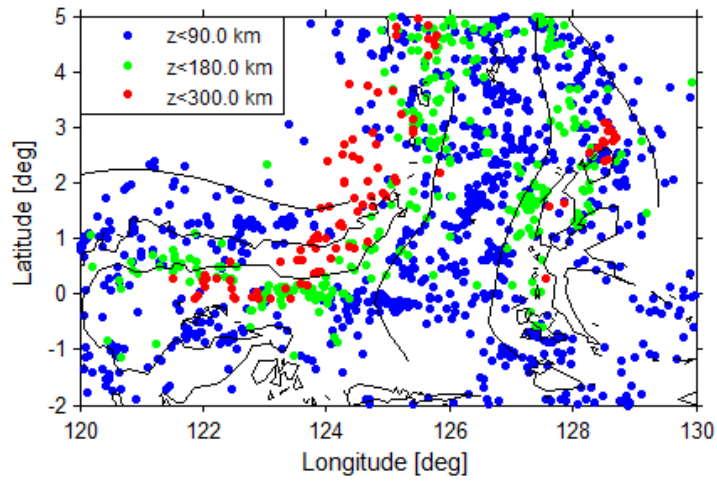

Gambar 4. Plot data gempa utama berdasarkan kriteria Gardner \& Knopoff (1974).

\section{Pemodelan Sumber Gempa}

Pemodelan sumber gempa dari suatu wilayah adalah merupakan tahap awal dalam analisa hazard gempa. Sumber gempa yang digunakan dalam studi ini terdiri dari 3 (tiga) yaitu, sumber gempa background, sumber gempa sesar (fault) dan sumber gempa subduksi (megathrust). Sumber gempa background dibagi menjadi dua yakni shallow background dengan kedalaman hingga $50 \mathrm{~km}$ dan deep background dengan kedalaman lebih dari $50 \mathrm{~km}$ hingga $300 \mathrm{~km}$.

Sumber gempa subduksi (megathrust) yang digunakan hingga kedalaman $50 \mathrm{~km}$, sedangkan kedalaman diatas $50 \mathrm{~km}$ diakomodasi oleh sumber gempa deep background. Sumber gempa subduksi yang ditinjau dalam studi ini berasal dari subduksi Sulawesi Utara. Sementara untuk sumber gempa sesar (fault) digunakan hingga kedalaman $30 \mathrm{~km}$.

\section{Sumber Gempa Subduksi}

Untuk sumber gempa subduksi (megathrust) Subduksi Sulawesi Utara berdasarkan data-data historik yang ada kemudian dilakukan analisa statistik dengan model maximum likelihood.

\section{Model Zona Sumber Gempa}

Analisa pemodelan sumber gempa atau probabilistic seismic hazard dilakukan dengan menggunakan software USGS PSHA 2007 (Harmsen, 2007) yang telah dubuatkan interfacenya oleh Bella, R.A (2008) dimana jarak spasi site adalah $0.1^{0} \times 0.1^{0}$ (lintang, bujur). Daerah penelitian dari $120^{\circ} \mathrm{BT}-130^{\circ}$ BT dan $2^{0} \mathrm{LS}-5^{0} \mathrm{LU}$. Analisa meliputi probabilitas terlampaui $10 \%$ dalam 50 tahun pada kondisi peak ground acceleration (PGA) atau pada periode $\mathrm{T}=0.0$ detik.

\section{Model Sumber Gempa Background:}

Identifikasi dan evaluasi tingkat seismic hazard terhadap sumber gempa dari background source perlu dilakukan dan dianalisa pada studi area Sulawesi Utara dan hasilnya ditampilkan pada Gambar 5.

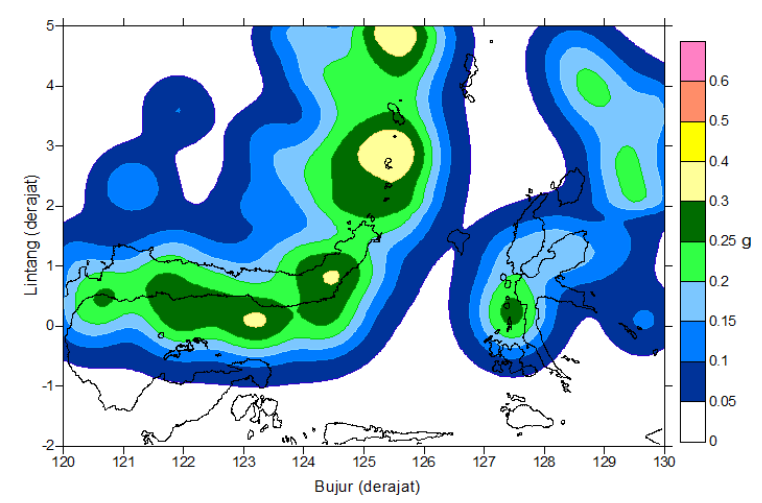

Gambar 5. Peta hazard di batuan dasar akibat sumber gempa background

Dari gambar dapat dilihat bahwa percepatan tanah maksimum di batuan dasar akibat sumber gempa background ini adalah sekitar 0.05-0.4g. Didaratan Sulawesi utara daerah yang mempunyai percepatan maksimum yang tinggi adalah sekitar Minahasa Selatan. Kemungkinan sumber gempa ini berasal dari gempa-gempa dalam akibat aktivitas tumbukan laut Maluku yang mengarah kea rah barat. Dari nilai percepatan yang tinggi ini, juga kemungkinan diakibatkan oleh adanya aktivitas sesar-sesar yang belum teridentifikasi dengan baik secara geologi.

\section{Model Sumber Gempa Fault:}

Model sumber gempa sesar (fault) yang digunakan dalam penelitian ini adalah Sulu Thrust, tumbukan ganda laut maluku (West Sangihe Thrust dan East Sangihe Thrust) dan Sesar Gorontalo. Peta percepatan puncak di batuan dasar untuk probabilitas terlampaui $10 \%$ dalam 50 tahun akibat sumber gempa fault ditampilkan pada Gambar 6. 


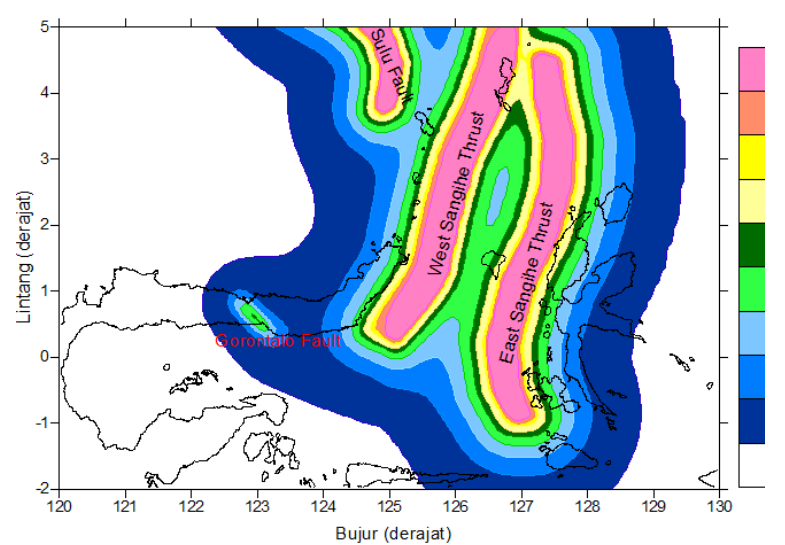

Gambar 6. Peta hazard di batuan dasar akibat sumber gempa Sesar (Fault)

Daerah-daerah yang mempunyai nilai percepatan yang cukup signifikan adalah daerah-daerah yang dekat atau berada pada lintasan sumber gempa fault seperti Kota Bitung, Gorontalo dan daerah-daerah sekitar bagian selatan Sulawesi utara. Besar nilai percepatan yang diakibatkan oleh sumber gempa sesar ini adalah sekitar 0.05$0.06 \mathrm{~g}$.

\section{Model Sumber Gempa Subduksi}

Peta percepatan puncak di batuan dasar untuk probabilitas terlampaui $10 \%$ dalam 50 tahun akibat sumber gempa subduksi (megathrust) ditampilkan pada Gambar 7. Pada Gambar 7 dapat dilihat bahwa peta percepatan puncak akibat sumber gempa subduksi (megathrust) memberikan nilai yang cukup signifikan pada daerah yang dekat dengan sumber dan pengaruhnya hingga jarak yang cukup jauh dari sumber.

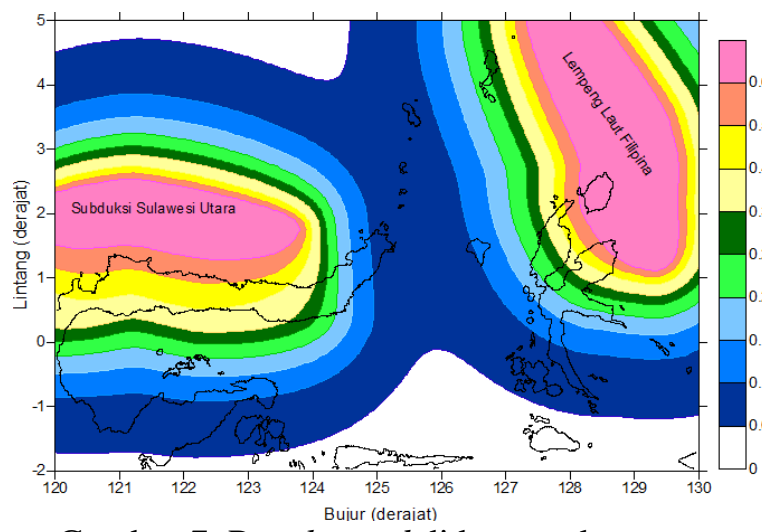

Gambar 7. Peta hazard di batuan dasar akibat sumber gempa Subduksi

Daerah-daerah yang mempunyai percepatan yang cukup tinggi akibat sumber gempa subduksi Sulawesi Utara adalah hampir sepanjang lengan utara Sulawesi. Sedangkan untuk penunjaman lempeng laut Filipina pengaruhnya cukup kecil hanya sekitar $0.05 \mathrm{~g}$. Besarnya percepatan puncak maksimum yang diakibatkan oleh sumber gempa megathrust ini adalah sekitar 0.05 $0.06 \mathrm{~g}$. Daerah yang sangat rentan terhadap sumber gempa ini adalah bagian utara lengan Sulawesi seperti Nampak pada gambar di atas.

\section{Model Sumber Gempa Gabungan (Combine Source)}

Peta percepatan puncak di batuan dasar akibat kombinasi ketiga sumber gempa untuk probabilitas terlampaui $10 \%$ dalam 50 tahun ditampilkan pada Gambar 8. Dari gambar di bawah dapat dilihat bahwa daerah-daerah yang mempunyai percepatan gempa yang cukup tinggi adalah daerahdaerah yang dekat dengan sumber gempa sesar (fault) dan sumber gempa subduksi (megathrust). Dari hasil perhitungan analisis seismik hazard diperoleh nilai percepatan gempa pada beberapa kota besar di Sulawesi Utara yang tertinggi adalah Kota Gorontalo dengan nilai percepatan sekitar $0,5 \mathrm{~g}$ kemudian disusul oleh Kota Bitung sebesar 0,4g, dan Kota Manado sebesar 0,25g.

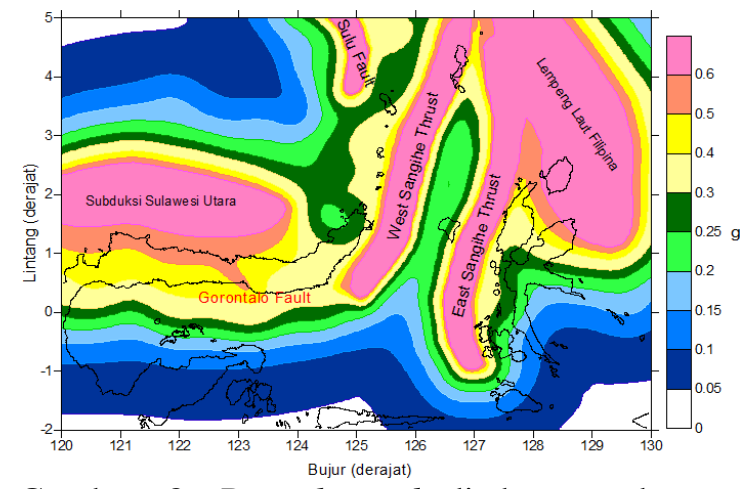

Gambar 8. Peta hazard di batuan dasar akibat gabungan (combine) sumber gempa

\section{KESIMPULAN DAN SARAN}

\section{Kesimpulan}

Dari pemodelan sumber gempa yang telah dilakukan ditarik beberapa kesimpulan bahwa: 
1. Wilayah Sulawesi Utara dan Sekitarnya adalah wilayah yang sangat rentan akan goncangan gempa bumi hal ini dapat dilihat dari peta percepatan gempa di batuan dasarnya.

2. Dari hasil perhitungan analisis hazard didapatkan nilai percepatan gempa di batuan dasar Sulawesi Utara dan sekitarnya pada kondisi peak ground acceleration (PGA) untuk probabilitas terlampui $10 \%$ dalam 50 tahun berkisar antara $0,05 \mathrm{~g}$ sampai $0,6 \mathrm{~g}$.

\section{Saran}

Perlu dilakukan penelitian yang lebih rinci tentang sesar-sesar aktif yang ada di wilayah Sulawesi termasuk parameterparameter yang digunakan dalam pemodelan agar dalam pemodelan sumber gempa dapat lebih teliti untuk memperkecil nilai kesalahan.

\section{DAFTAR PUSTAKA}

Bella, R.A. 2008. Pembuatan Program Interface Untuk Software USGS PSHA 2007 Dengan Studi Kasus Pembuatan Peta Spectra Hazard di Wilayah Nusa Tenggara Timur. Thesis Magister Teknik Sipil. Institut Teknologi Bandung.

Bock, Y., L. Prawirodirdjo, J.F. Genrich, C.W. Stevens, R. McCaffrey, C. Subarya, S.S.O. Puntodewo, dan E. Calais. 2003. Crustal motion in Indonesia from Global Positioning System measurements. Journal of Geophysical Research 108 No. B8 2367.

Gardner, J.K. dan L. Knopoff. 1974. Is the sequence of earthquakes in southern California, with aftersocks removed, Poissonian?. Bulletin of the Seimological Society of America, 64, 1363-1367.

Hall, R. and M.E.J. Wilson. 2000. Neogene Sutures in Eastern Indonesia. Journal of Asian Earth Sciences, 18, 781-808.
Harmsen, S. 2007. USGS Software For Probabilistic Seismic Hazard Analysis (PSHA). United States of Geological Surveys (USGS).

Irsyam, M., M. Asrurifak, Hendriyawan, B. Budiono, Triyoso dan B.Hutapea. 2008. Usulan Revisi Peta Seismic Hazard Indonesia Dengan Menggunakan Metode Probabilitas dan Model Sumber Gempa Tiga Dimensi. PIT XII HATTI, Bandung.

McGuire, R.K. 1995. Probabilistic Seismic Hazard Analysis and Design Earthquakes: Closing the Loop. Bulletin of the Seismological Society of America 85(5), 1275-1284.

Scordilis, E.M. 2006. Empirical Global Relations Converting $M_{S}$ and $M_{b}$ to Moment Magnitude, Journal of Seismology, 10, 225-236.

Simandjuntak, T.O. 1992. An Outline of Tectonics of the Indonesian Region. Geological News Letter, 252(3), 4-6. Geological Research and Development Center, BandungIndonesia.

USGS, Probabilistic Seismic Hazard Analysis. http://earthquake.usgs.gov/ research/hazmaps/

Widiyantoro, S. 2007. Fisika dan Struktur Intrior Bumi. Penerbit Badan Meteorologi dan Geofisika Jakarta, ISBN 978-979-1241-06-09.

Wiemar, S. 2001. A software package to analyze seismicity: ZMAP. Seismological Research Letters, 72(2), 373-382. 